\title{
The Relationship Between Governance and Economic Growth During Times of Crisis
}

\author{
By \\ Bassam A. AlBassam ${ }^{1} \mathrm{PhD}$
}

\begin{abstract}
The current economic crisis has affected all aspects of life, resulting in political instability, personal financial troubles, and a growing number of business bankruptcies. Although these are serious issues, simply developing a government policy that injects an economy with money is not an appropriate means to achieve economic recovery and long-term economic development unless combined with an effective and efficient governing system. The present article examines whether the strong relationship between governance and growth exists during economic crises or only during non-crisis periods. The results of the current paper demonstrate that the global economic crisis has had an unnoticeable influence on the relationship between governance and economic growth. However, this study found that different levels of development of nations affect the relationship between governance and growth in various ways during times of crisis. Thus, the results of the current paper highlight the instability in the relationship between governance and economic growth during the economic crisis; this unsteadiness is a sign of the need for long-term strategies to promote global and national good governance practices that are not adversely affected by crises.
\end{abstract}

Key Words: quality of governance, economic growth, economic crisis, human development.

\section{Introduction}

The economic crisis of 2008 has affected all aspects of life, resulting in political instability, personal financial troubles, and a growing number of business bankruptcies. Although these are serious issues, simply developing a government policy that injects an economy with money is not an appropriate means to achieve economic recovery and long-term economic development unless combined with an effective and efficient governing system (Albassam, 2012a; Aikins, 2009; Davidoff \&Zaring, 2008; Reinhart \&Rogoff, 2009). According to Aikins (2009), "without appropriate economic policy and regulatory framework, a nation's financial system becomes vulnerable to crisis and jeopardizes the stability of the entire economy" (p. 39). 
Economic growth has been connected to government practices and the way governments govern both directly and indirectly (Adams \&Mengistu, 2008; Ndulu\& O'Connell, 1999; Pradhan\&Sanyal, 2011). In addition, governing processes are affected by economic crises (Furubotn\& Richter, 2005; Smith, 2007). For decades, international organizations (IOs) such as the International Monetary Fund (IMF), the United Nations, and the World Bank have argued that good governance is a means to an ends like economic growth and human development (Kaufmann \&Kraay, 2002; Mehanna, Yazbeck, \&Sarieddine, 2010; United Nations, 2000). Scholars and researchers agree that a strong relationship exists between economic growthand governance, yet it is debatable whether good governance practices lead to economic growthor whether economicgrowthleads to good governance (Acemoglu, Johnson, \& Robinson, 2001; Arndt \& Oman, 2006; Dixit, 2009; Kaufman, Kraay, \&Mastruzzi, 2009b; Smith, 2007).

Many research efforts have discussed possible causes of the current crisis, including lack of local regulations to organize financial markets (Bernanke, 2009; Reinhart \&Rogoff, 2009), government failure (Albassam, 2012b; Davidoff \&Zaring, 2008; Gruenewald, 2010), and international organizations' failure to take action to organize the global market (Cerra\&Saxena, 2008; Langmore\& Fitzgerald, 2010; Repucci, 2011). However, research on the influence of the current economic crisis on shaping the relationship between governance and economic growth is severely lacking. Besides filling the gap caused by the shortage of research on the subject, developing a clear understanding of the influence of the 2008 economic crisis on the relationship between governance and growth will have important implications for both local and global political and decision-making processes.

In general, governments typically respond to crises with short-term remedial plans, potentially resulting in a harmful long-term economy recovery (Davidoff \&Zaring, 2008; Reinhart \&Rogoff, 2009). In addition, Davidoff and Zaring (2008) argued that governments focus more on economic growth than on governance development during economic crises. Thus, if the influence of economic crises on the relationship between governance and growth is understood, governments can be encouraged to adopt strategies that will enhance governance quality and economic growth in the long run without sacrificing good governance practices in the short run. Consequently, studying economic growth and its relationship to the governing process will help explain the factors that influence it during times of crisis and the ways in which it might be improved.

For decades, international organizations (IOs)such as the United Nations, the IMF, and the World Bank, have supported good governance practices as a means for human development and economic growth (Mimicopoulos et al., 2007; Santiso, 2001; United Nations, 2007). However, during crises, most countries score low in governance indicators because their governments concentrate more 
on economic growth than on adopting and improving good governance practices (Davidoff \&Zaring, 2008; Kaufman et al., 2009 \& 2010; Reinhart \&Rogoff, 2009). Thus, understanding the role that economic crises play in shaping the relationship between governance and growth during crises will encourage IOs to adopt long-term strategies of promoting global good governance practices that are not adversely affected by crises.

In addition, human development has been associated with quality of governance (Alkire, 2010; Grindle, 2007; Pradhan\&Sanyal, 2011; Sagar\&Najam, 1998), economic growth (Adams \&Mengistu, 2008; Ndulu\& O'Connell, 1999; Smith, 2007), and sustainable development (Alkire, 2010; Ndulu\& O'Connell, 1999; Sagar\&Najam, 1998). According to Pradhanand Sanyal (2011), "the issue of good governance and its impact on development is the heart of all policy debates among the policy makers and researchers" (p. 3).

According to Alkire (2010), reciprocal relationships exist among good governance, economic growth, and human development. Alkire (2010) concluded that human development (examples of which include high-quality education and health systems) supports the productivity of an economy by providing healthy and highly trained individuals. To this end, human development requires both economic growth and good governance practices by governments (Alkire, 2010). Thus, the current article discusses the nature of the relationship among human development, good governance, and economic growth during times of crisis. To study the influence of a nation's development level on the relationship between governance and growth during times of crisis, the human development index (HDI) - a product of the United Nations Development Program-is used in the current paper.

North (1990) explained that institutional structure and design impact economic and political outcomes. In addition, human development influences economic growth and the way governments govern (Albassam, 2012a; Provan\&Kenis, 2007; Smith, 2007). Thus, analyzing the influence of a particular nation's level of development on shaping the relationship between economic growth and governance, both before and after the beginning of the economic crisis, will help understand the relationship between institutional and human development on the one hand and economic growth on the other hand, particularly during times of economic crisis.

This article is organized as follows. Economic growth and quality of governance concepts are discussed first, followed by an exploration of the economic crisis timeline. The methodology used to test the relationship between quality of governance and growth will then be explained in addition to a discussion of the results of the analysis. The last section discusses the findings of the current article and presents suggestions for further research. 


\section{Economic Growth}

Although no universally agreed-upon definition of economic development exists, a commonality among researchers is emerging that economic development results in better lives for people and is necessary for a strong longterm national economy. Economic development implies both the improvement of people's health, education, and general well-being and the presence of positive economic indicators, such as economic growth and low unemployment rates (Adams \&Mengistu, 2008; Aidt, 2009; Arndt, 1987). Sustainable development is another issue related to economic development because, without strong longterm economic growth, an economy will be in danger of collapsing during any economic or political crisis (Blair \& Carroll, 2008; Mayer-Foulkes, 2009; Nafziger, 2006; Ndulu\& O'Connell, 1999).

Economic development is important because it has implications on people's lives (Adams \&Mengistu, 2008; Chong \& Calderon, 2000; Kaufmann \&Kraay, 2002; Smith, 2007). With economic development, people will have better education and healthcare and be more productive (Agere, 2000; Mimicopoulos et al., 2007). Economic development also affects crime rates and political stability (Przeworski, Alvarez, Cheibub, \&Limongi, 2000) as better-developed nations tend to have lower crime rates and greater political stability than less-developed countries (Abdellatif, 2003; Adams \&Mengistu, 2008; Kaufmann \&Kraay, 2002).

Consequently, economic growth concerns all nations trying to increase their GDP per capita in order to increase their citizens' well-being (Adams \&Mengistu, 2008; Mankiw, 2009; UNDP, 2010). Although scholars continue to debate whether it is a consequence of human development or a precondition for human development, economic growth is considered an important component of economic and human development. Smith (2007) found that human development and economic development need each other; as such, countries cannot concentrate on one and ignore the other. According to Smith (2007), "there is in effect a virtuous circle of human development and economic development, each enhancing the other" (p. 14). In addition, the United Nations Development Program (UNDP) demonstrated that economic growth, education, and health are the key parts of human development, with each part dependent on the others. According to the UNDP (2000), "resources generated by economic growth have financed human development and created employment while human development has contributed to economic growth" (p. 7).

Economic growth is the increase of real gross domestic product (GDP) or other measurements of aggregate income. According to the World Bank (2004), economic growth is "quantitative change or expansion in a country's economy" (par. 10). In addition, the World Bank (2004) contended that "economic growth 
is conventionally measured as the percentage increase in gross domestic product (GDP) or gross national product (GNP) during one year" (par. 10).

After acknowledging the existence of the relationship between economic growth and human development, the Human Development Reports (HDRs, 2010) indicated that the direction of the relationship is not clear cut. According to the HDRs (2010), "even if there is a causal relation, the direction is unknown: higher incomes could improve quality of life, or improvements in health and education could make societies more productive" (p. 48). In addition, both the income distribution among citizens and the quality of goods and services produced are as important for any nation as increasing income levels. According to Petrovskiy(2009), "from a human development perspective, the quality of economic growth is just as important as its quantity" (p. 134).

Furthermore, economic growth has been linked to governance improvement (Albassam, 2012a; Furubotn\& Richter, 2005; Kaufman \&Kraay, 2008; Mantzavinos, 2001). Kaufmann and Kraay (2002) argued that governance quality and economic growth are positively related. In their evaluation of the worldwide governance indicators (WGI) from 1996 to 2002, they found that "per capita incomes and the quality of governance are strongly positively correlated across countries" (p. 1).

Accordingly, the relationship between economic growth and quality of governance impacts international aid assistance from countries such as the U.S. and the U.K. and from international organizations such as the World Bank and the IMF. According to Mehanna et al.(2010), "the issue of causality between governance and economic development is crucial and has many implications from an international agency perspective; resolving this issue would assist international organizations in their choices between prioritizing pro-growth or institutional policies" (p. 123). Therefore, the power and direction of the relationship between economic growth and governance have been and will continue to be the subject of disagreement among policymakers and those in academia (Acemoglu et al., 2001; Alkire, 2010).

\section{Governance}

The concept of governance has been discussed in political science and public administration research for decades. Governance has been introduced as an alternative to traditional methods of governing (Kettl, 2002; Rhodes, 1997). In the traditional approach to governing, government has the upper hand in decision-making processes (Hysing, 2009; Peters \& Pierre, 1998); in contrast, under governance, other players affected by governmental decisions (e.g., civil society and the private sector) participate in decision-making processes (Kettl, 2002; Newman, 2001; Osborne \&Gaebler, 1992; Rhodes, 1997). Although no 
consensus exists in terms of defining governance, a common theme among scholars is that governance means more participation in the political and decision-making process by nongovernmental institutions (Agere, 2000; de Ferranti, Jacinto, Ody, \&Ramshaw, 2009; Lovan, Shaffer, \& Murray, 2004). Thus, under governance, government is one of several players-rather than the only player-managing a nation's affairs (Frahm\& Martin, 2009; Kettl, 2002; Lovan et al., 2004; Rhodes, 1997).

According to de Ferranti et al. (2009), "governance describes the overall manner in which public officials and institutions acquire and exercise their authority to shape public policy and provide public goods and services" (p. 8).Governance "represent[s]the overall quality of relationship between citizens and government, which includes responsiveness, efficiency, honesty, and quality" (p. 8). Similarly, the United Nations defined governance as "the process of decision-making and the process by which decisions are implemented (or not implemented)" (United Nations Economic and Social Commission for Asia and the Pacific [UNESCAP], 2009, p. 1).

The United Nations also introduced characteristics of good governance practices as a global standard to be adopted by governments that receive their aid. According to the United Nations, "good governance has 8 major characteristics; it is participatory, consensus oriented, accountable, transparent, responsive, effective and efficient, equitable and inclusive, and follows the rule of law" (UNESCAP, 2009, p. 1). These criteria are often used by IOs and recipient nations to assess how their governments are achieving better governance (Mimicopoulos et al., 2007). Furthermore, IOs have argued that good governance positively affects the quality of government work, the way services are provided to their citizens, and the way programs are executed (Agere, 2002; Mimicopoulos et al., 2007).

As international donors (whether countries or international organizations like the IMF and the World Bank) seek the best use of aid to achieve economic development in receiving countries, these donors use good governance characteristics introduced by IOs to evaluate the performance of receiving governments. Although scholars and politicians have debated the practicality of using the good governance characteristics introduced by IOs as a measure of governing quality (Farazmand, 2002; Poluha\&Rosendahl, 2002), good governance characteristics have undoubtedly gained creditability among IOs and politicians as well as-most noteworthy-in academic research (Albassam, 2012a; Arndt \& Oman, 2006). In addition, in many cases, these characteristics play a major role in the approval of loans or direct aid by international donors to countries in need (Mimicopoulos et al., 2007; Santiso, 2001). 


\section{Economic Crisis}

The economic crisis of the late 2000s caused many countries to suffer politically and economically as a result of weak economic infrastructures at both the global and local levels. The absence of regulations to organize the financial markets (Bernanke, 2009; Davidoff \&Zaring, 2008; Reinhart \&Rogoff, 2009) and the lack of sustainable prior economic growth that might have minimized the impact of the crisis (Acha, 2011; Agarwal, 2009; Aikins, 2009; Mayer-Foulkes, 2009) are major contributing factors to the weakness and instability of the national and global economics, which resulted in the vulnerability of local economies in facing the global economic crisis (Albassam, 2012b; Baily \& Elliot, 2009; Bernanke, 2009; Simkovic, 2011).

The term economic crisis refers to a general slowdown of economic activity characterized by a decrease in GDP, a drying up of liquidity, and a high rate of unemployment (Begget al., 2009; Gressani\&Kouame, 2009; Sirimanne, 2009). Globally, an economic crisis results in decreased international trade and investment (Claessens\&Kose, 2009; National Bureau of Economic Research [NBER], 2012). In addition, an economic crisis might lead to a recession, which has been the case for most countries over the last several years. According to the NBER (2003), two consecutive quarters of negative economic growth means that an economy is in recession. It takes time for economies to recover from the longterm influences of a recession (Aikins, 2009; Cerra\&Saxena, 2008; Langmore\& Fitzgerald, 2010).Many reports from international organizations, independent institutions, and country officials have discussed the economic crisis and proposed timelines for recovery. Although the influence of the economic crisis has varied among countries (e.g., some oil-exporting countries have not experienced the economic crisis to the same extent as other countries), it is certain that almost all countries have felt the impact of the crisis in one way or another (Gressani\&Kouame, 2009; Sirimanne, 2009; United Nations Conference on Trade and Development [UNCTD], 2009).

Although there is no exact date for when the economic crisis started, nor is there an exact date to say that the economic crisis was a global crisis, officials in many countries (e.g., Ireland, Denmark, and Estonia) have announced that their economies entered a recession period in 2008 (Statistics Denmark, 2009; Statistics Estonia, 2012). In addition, annual economic reports for 2009 from both countries and international organizations showed a decline in global and national GDP in 2008, international trade activities such as foreign direct investment (FDI), and exports and imports between countries (UNCTD, 2009). In addition, a significant number of requests for financial assistance from countries affected by the economic crisis were made in 2008 and beyond to the IMF, the World Bank, and strong economies such as China (IMF, 2010; World Bank, 2012a). 
Finally, in 2008, many countries took economic and political actions in response to the crisis, such as the Emergency Economic Stabilization Act of 2008 in the United States, the Economic Resiliency Plan (ERP) of 2008 in the Philippines, and the creation of agencies such the National Asset Management Agency in Ireland (Baily \& Elliot, 2009; Simkovic, 2011; Yap et al., 2009). Thus, 2008 has been touted as the beginning of the global economic crisis and will also be used as such for the purposes of the present paper.

Although 2008 is used to mark the beginning of the crisis, it is important to understand that the global economic crisis did not arise in a single year; rather, it resulted from a series of earlier events, such as the housing bubble of 2006 and 2007 (Bernanke, 2009; Davidoff \&Zaring, 2008; Reinhart \&Rogoff, 2009). Furthermore, although the economic crisis became a global issue in 2008, its influence was felt differently among various nations. Some countries, such as Ireland, Greece, and Spain, faced massive economic and political turbulence after the crisis began whereas others, such as oil-rich countries and China, felt the consequences of the crisis through slow economic growth (Gressani\&Kouame, 2009; Sirimanne, 2009).

\section{Measures and Research Methodology}

The current article was based on credible and reliable sources of data that measure governance quality and economic growth (Arndt \& Oman, 2006; Mimicopoulos et al., 2007). Many studies, policymakers, and IOs have used the same sources to measure these variables (Albassam, 2012a \& 2012b; Arndt \& Oman, 2006; Kaufmann \&Kraay, 2002; Mehanna et al., 2010). The process of analyzing data will be an exploratory process using countries' GDP data, WGI scores, and HDI scores. In addition, this study includes secondary data collected from worldwide governance indicators, the World Bank, and the UNDP. The sample framework to be included in this study includes all United Nations' members covered by the worldwide governance indicators (as a measure of governance) and have GDP (as a measure of economic growth) data available from 2006 to 2011. In the current paper, GDP per capita at purchasing power parity (PPP) in the current international dollar is used to measure economic growth. GDP per capita is calculated by dividing a country's GDP by its total population (Constanza et al., 2009; Shostak, 2001; Vachris\& Thomas, 1999), whereas PPP is calculated based on countries' price level of a fixed basket of goods and services. PPP uses market exchange rates and a basket of goods and services across countries as the basis for comparisons among countries (Ignatiuk, 2009; Vachris\& Thomas, 19990). In addition, this paper uses PPP because it acknowledges the population increase and cost of living of each country (Ignatiuk, 2009; Nguyen, 2005; Vachris\& Thomas, 1999). 
According to Wong and Autio (2005), "GDP per capita is the most commonly used measure of economic growth" (p. 346, note). Many studies have used GDP per capita adjusted for PPP as a measure of economic growth (Adam, 2003; Albassam; 2012a; Calderón\& Liu, 2002; De Long \& Summers, 1991; Harttgen, 2012; Islam, 1998; Kentor, 1998; Wong \&Autio, 2005; van den Bergh, 2009). Following these studies' format, GDP per capita adjusted for PPP is used in the current paper as a measure of economic growth.

For the purposes of the current paper, six governance indicators are used to measure the quality of governance: voice and accountability, political stability and absence of violence, regulatory quality, rule of law, government effectiveness, and control of corruption (Kaufman et al., 2009). The current paper adopted WGI as a measure of governance quality because it measures the efficiency and effectiveness of government work (using the rule of law, regulatory quality, and government effectiveness indicators) as well as the extent to which governments fight corruption and encourage citizens to participate in the political process (using the control of corruption, political stability and absence of violence/terrorism, and voice and accountability indicators) (Kaufmann et al., 2010).

The six WGIs were used by Kaufmann et al. (2010) to measure quality of governance. Policymakers, IOs, and academic scholars have also used WGI to evaluate countries' affairs and determine to what extent governments apply good governance characteristics, such as public participation in the political process or the fighting of corruption (Arndt \& Oman, 2006; Langbein\& Knack, 2010; Thomas, 2008). WGIs are published annually by The World Bank Group. The first WGI edition, published in 1996, covered 186 countries; the edition published in 2011 covered the economies of 215 countries and territories.

The level of influence of the current economic crisis on shaping the relationship between economic growth and governance is expected to vary from one indicator to another. Having six indicators focusing on different aspects of the governance process, rather than one aggregate index of governance, enables decision makers and researchers to understand the relationship between each aspect of the governance process and economic growth during times of crisis. In addition, decision makers can develop a clear understanding of the role that each indicator plays in enhancing economic growth during crisis periods.

In addition to studying the relationship between governance and economic growth, this paper investigates whether such a relationship is the same across nations during times of crisis. The current paper addressed four groups of countries based on their human development level, using the United Nations' HDI. These four groups are classified into the following categories: very high development, high development, medium development, and low development (UNDP, 2010). The United Nations uses the HDI to measure human 
development factors such as adult literacy, levels of education, and healthcare. The purpose of using countries' development levels in this paper is to study the relationship between each country's level of development and the impact of the economic crisis on shaping the relationship between governance and economic growth in that country. In other words, this paper attempts answer the following question: Does the effect of the economic crisis on the relationship between economic growth and governance vary from country to country based on each country's level of development?

Testing whether the relationship between governance and economic growth was affected by the economic crisis of 2008 required comparing the levels of the relationship both before (2006-2008) and after (2009-2011) the beginning of the crisis. If the nature of the relationship changed after the crisis began, it would indicate that the economic crisis affected the relationship between governance and economic growth. In contrast, if the nature of the relationship has not changed, this would indicate that the economic crisis has not affected the relationship. This method will be applied to all countries and to each of the four development groups of nations discussed in the paper.

With regard to this current set of analyses, a series of sets of pairwise correlations were conducted between GDP and all six governance indicators separately based on HDI (Group 1: very high development; Group 2: high development; Group 3: low development; Group 4: low development) as well as separately based on time period (all years, before the financial crisis, and after the onset of the global economic crisis). All analyses were conducted using Stata 11 after reshaping the data from wide to long format.

Regarding sample size, the full data set included data on 215 countries, with the sample sizes not changing based on time period (i.e., sample sizes with respect to the number of countries did not change regardless of whether the analysis was conducted on the entire data set, before the financial crisis, or after the onset if the global economic crisis). In addition, because the nations' classification regarding the development level omits some countries (some countries were not classified into any development group), in the current paper categorized 46 countries as very high development (Group 1), 45 countries as high development (Group 2), 47 countries as low development (Group 3), and 46 countries as low development (Group 4).

\section{Results and Discussion}

Initially, correlations were conducted between GDP and each indicator of the six governance indicators for all countries using data from 2006 to 2011. Table 1 demonstrates significant, strong, and positive correlations between each governance indicator and GDP after the beginning of the global economic crisis, 
with all correlations being above 0.50 at the significant level $\alpha=0.01$. These significant relationships do not change notably after the beginning of the global economic crisis.

Table 1: Correlations between variables for all countries

\begin{tabular}{|c|l|l|l|l|l|l|}
\hline $\begin{array}{c}\text { Time } \\
\text { Periods }\end{array}$ & CC\&GDP & GE\&GDP & PS\&GDP & $\begin{array}{c}\text { RL\&GD } \\
\text { P }\end{array}$ & RQ\&GDP & VA\&GDP \\
\hline $06-11$ & $0.76^{*}$ & $0.77^{*}$ & $0.56^{*}$ & $0.74^{*}$ & $0.74^{*}$ & $0.47^{*}$ \\
\hline $06-08$ & $0.76^{*}$ & $0.76^{*}$ & $0.57^{*}$ & $0.73^{*}$ & $0.74^{*}$ & $0.46^{*}$ \\
\hline $09-11$ & $0.76^{*}$ & $0.78^{*}$ & $0.56^{*}$ & $0.76^{*}$ & $0.74^{*}$ & $0.49^{*}$ \\
\hline
\end{tabular}

Note: *Significant relationship at $\alpha=0.01$; voice and accountability (VA), political stability (PS), regulatory quality (RQ), rule of law (RL), government effectiveness (GE), and control of corruption (CC); gross domestic product (GDP).

The influence of the nation's development level on the relationship between governance and economic growth during times of crisis is discussed in Table 2. In the very high development level (Group 1), strong, significant, and positive correlations were found between GDP and the control of corruption (CC), while significant, positive, and moderate correlations were found with respect to GDP and the remaining indicators, with the exception of voice and accountability (VA) in the all years analysis. The correlation between GDP and VA for Group 1 was found to be significant, albeit weak and negative. After the beginning of the economic crisis, the relationships between governance indicators and GDP became more positive compared to before the crisis began; however, VA is the only indicator that its relationship with GDP became non-significant after the beginning of the crisis.

In the high development level (Group 2), significant, positive, and moderate relationships were found between GDP and CC and rule of law (RL), whereas significant, positive, and weak relationships were found between GDP and government effectiveness (GE), political stability (PS), and regulatory quality (RQ). The relationship between VA and GDP was not found to be significant. In contrast, after the beginning of the economic crisis, the relationships were not found to be substantially different from before the crisis, with the exception of the relationship between RQ and GDP, which failed to achieve statistical significance at the 0.01 significance level.

In the medium development nations (Group 3), when focusing upon the entire time span, significant, weak, and negative relationships were found between GDP and GE as well as VA. A significant, weak, and positive correlation was found between PS and GDP. The relationships conducted before the financial crisis only found one significant relationship: a relationship of the same magnitude between PS and GDP. Finally, the set of relationships conducted after the beginning of the economic crisis found no significant results.

The final set of relationships, focusing upon the low development nations (Group 4), also found few significant results. When focusing upon the entire data 
set, a significant, negative, although weak relationship was found between GDP and CC, while a significant, weak, and positive relationship was found between GDP and RQ. The relationships conducted before the financial crisis found no significant results, whereas the relationships conducted after the onset of the financial crisis only found a similar weak and negative relationship between GDP and CC to achieve significance at the 0.01 significance level.

Table 2: R-Values (Correlation) for nations' development level

\begin{tabular}{|c|c|c|c|c|c|c|c|}
\hline $\begin{array}{c}\text { Time } \\
\text { Periods }\end{array}$ & Groups & $\begin{array}{l}\text { CC\& } \\
\text { GDP }\end{array}$ & $\begin{array}{l}\text { GE\& } \\
\text { GDP }\end{array}$ & $\begin{array}{l}\text { PS\& } \\
\text { GDP }\end{array}$ & $\begin{array}{l}\text { RL\& } \\
\text { GDP }\end{array}$ & $\begin{array}{l}\text { RQ\& } \\
\text { GDP }\end{array}$ & $\begin{array}{l}\text { VA\& } \\
\text { GDP }\end{array}$ \\
\hline $06-11$ & Group 1 & $0.52^{*}$ & $0.42^{*}$ & $0.40^{*}$ & $0.40^{*}$ & $0.32^{*}$ & $-0.17^{*}$ \\
\hline $06-08$ & Group 1 & $0.48^{*}$ & $0.39^{*}$ & $0.38^{*}$ & $0.37^{*}$ & $0.31^{*}$ & $-0.19^{*}$ \\
\hline $09-11$ & Group 1 & $0.58^{*}$ & $0.48^{*}$ & $0.43^{*}$ & $0.45^{*}$ & $0.33^{*}$ & -0.13 \\
\hline $06-11$ & Group 2 & $0.36^{*}$ & $0.28^{*}$ & $0.26^{*}$ & $0.37^{*}$ & $0.20^{*}$ & -0.05 \\
\hline $06-08$ & Group 2 & $0.40^{*}$ & $0.30^{*}$ & $0.28^{*}$ & $0.39^{*}$ & $0.23^{*}$ & -0.03 \\
\hline $09-11$ & Group 2 & $0.30^{*}$ & $0.26^{*}$ & $0.23^{*}$ & $0.33^{*}$ & 0.13 & -0.09 \\
\hline $06-11$ & Group 3 & -0.08 & $-0.13^{*}$ & $0.17^{*}$ & -0.05 & -0.03 & $-0.17^{*}$ \\
\hline $06-08$ & Group 3 & -0.07 & -0.11 & $0.17^{*}$ & -0.05 & 0.00 & -0.16 \\
\hline $09-11$ & Group 3 & -0.09 & -0.16 & 0.17 & -0.04 & -0.07 & -0.20 \\
\hline $06-11$ & Group 4 & $-0.18^{*}$ & 0.10 & 0.06 & -0.04 & $0.14 *$ & -0.06 \\
\hline $06-08$ & Group 4 & -0.14 & 0.11 & 0.07 & -0.05 & 0.14 & -0.08 \\
\hline $09-11$ & Group 4 & $-0.23^{*}$ & 0.09 & 0.04 & -0.02 & 0.13 & -0.03 \\
\hline
\end{tabular}

Note: $*$ Significant relationship at $\alpha=0.01$; voice and accountability (VA), political stability (PS), regulatory quality (RQ), rule of law (RL), government effectiveness (GE), and control of corruption (CC); Group 1=very high development; Group 2=high development; Group 3=medium development; Group 4=low development; gross domestic product (GDP).

\section{Conclusion and Recommendation}

The notion of governance has been one of the most discussed and debated issues in recent years in the social sciences and other fields. Governance has also been associated with human and economic development. Economic growth, on the other hand, is a primary concern of nations, even more so during times of crises. Accordingly, the current global economic crisis has influenced all aspects of people's lives, including the relationship between governance and economic growth.

The literature demonstrates the existence of the relationship between governance and economic growth, but says little about the influence of the economic crisis on that relationship. The current article showed no remarkable changes in these relationships: Relationships between economic growth as 
measured by GDP per capita and each indicator of the governance indicators were both significant before and after the onset of the 2008 economic crisis.

Interestingly, analyzing the influence of a nation's development level on the relationship between governance and economic growth during times of crisis showed different relationships between governance indicators and growth among nations with different development levels. In very high development nations, all relationships between governance and economic growth were significant after the beginning of the global economic crisis except for the relationship between VA and GDP. In high development nations, all relationships between governance and economic growth were significant after the beginning of the global economic crisis except the relationships between VA and GDP and between RQ and GDP. In medium development nations, none of the relationships between governance indicators and GDP were significant after the onset of the global economic crisis. Finally, in less developed nations, CC was the only indicator that showed a significant relationship with GDP after the beginning of the global economic crisis.

This article found that the levels of nations' development affected the relationship between governance and growth differently during times of crisis. In other words, a country's level of development influences the effect of the economic crisis on shaping the relationship between governance and growth. Consequently, countries with different levels of development have different requirements and demands to improve governance and enhance economic growth during times of crisis. Thus, this result is consistent with governance literature discussing the influence of a country's level of development on shaping the relationship between governance and growth.

The current article contributes to the literature by studying the relationship between governance and growth during times of crisis. Much research could be built on the results of the current research. As in most research, using more variables will add more value to the research; however, some variables might contribute more than others in analyzing the influence of the economic crisis on shaping the relationship between governance and growth. For example, a country's type of political system might influence the way the economic crisis shapes the relationship between governance and growth in that country. Accordingly, studying whether governments govern differently during times of crisis as a result of the structure of their countries' political systems is another suggested topic.

In addition, further research could study specific regions or economies. As previously discussed, transitional economies such as China and India and oil-rich economies such as Saudi Arabia and Qatar have special characteristics that shape the relationship between governance and growth during times of crisis. Thus, studying the influence of the economic crisis on the relationship between 
governance and growth in these economies will contribute to our understanding of the governance process and its relationship to economic and human development.

\section{References}

Abdellatif, A. (2003). Good Governance and Its Relationship to Democracy and Economic Development. Proceedings from: Global Forum III on Fighting Corruption and Safeguarding Integrity. Seoul, South Korea. Retrieved 09-21-2010 from http://www.pogar.org/publications/governance/aa/goodgov.pdf.

Acemoglu, D., Johnson, S. \& Robinson, J. (2001). The Colonial Origins of Comparative Development: An Empirical Investigation. American Economic Review, 91 (5), p. 13691401.

Acha, I. (2011). Financial Derivatives, Global Economic Crisis and Less Developed Countries (LDCs). Journal of Economics and International Finance, 2(9), 508-512.

Adam, R. (2003). Economic Growth, Inequality, and Poverty Findings from a New Data Set.The World Bank (Policy Research Working Paper No. 2972). Retrieved 10-30-2012 From http://www-

wds.worldbank.org/servlet/WDSContentServer/WDSP/IB/2003/03/22/000094946_0 3030704153293/Rendered/PDF/multi0page.pdf

Adams, S., \&Mengistu, B. (2008).Privatization, Governance and Economic Development in Developing Countries.Journal of Developing Societies, 2, p. 415-438.

Agere, A. (2000). Promoting Good Governance: Principles, Practices and Perspectives (Managing the Public Service: Strategies for Improvement Series). London, UK: Commonwealth Secretariat.

Aidt, T. (2009).Corruption, Institutions and Economic Development.Oxford Review of Economic Policy, 22 (2), 203-225.

Aikins, S. K. (2009). Global Financial Crisis and Government Intervention: A Case for Effective Regulatory Governance. International Public Management Review, 10 (2), 23-43.

Albassam, B. (2012a). The Influence of the Economic Crisis on the Relationship between Governance and Economic Growth.(Unpublished doctoral dissertation).Florida Atlantic University, Boca Raton, FL, USA.

Albassam, B. A. (2012b). Money Talks: The Influence of Economic Crisis on Global Governance. Mediterranean Journal of Social Sciences, 3 (2), 117-128.

Alkire, S. (2010).Human Development: Definitions, Critiques, and Related Concepts. Human Development Reports (Research Paper 2010/01). Retrieved 06-20-2011 from http://hdr.undp.org/en/reports/global/hdr2010/papers/HDRP_2010_01.pdf.

Arndt, C., \& Oman, C. (2006).Uses and Abuses of Governance Indicators. Paris, France: Development Centre Studies, OECD Publishing. Retrieved 06-20-2010 from http://www.worldbank.org/ieg/governance/oman_arndt_paper.pdf.

Arndt, H. W. (1987). Economic Development: The history of an Idea. Chicago: Universityof Chicago.

Baily, M. N., \& Elliott, D. J. (2009).The U.S. Financial and Economic Crisis: Where Does It Stand and Where Do We Go From Here? The Brookings Institution, Fixing Finance Series (Working \# 7).Retrieved 03-06-2012 from http://www.brookings.edu/papers/2009/0615_economic_crisis_baily_elliott.aspx.

Begg, D., De Grauwe, P., Canova, F., Fatas, A., \& Lane, P. (2002).Surviving the Slowdown Monitoring the European Central Bank No.4). London, UK: Centre for Economic Policy Research. 
Bernanke, B. S. (2009, April 14). Four Questions about the Financial Crisis. Speech presented At the Morehouse College, Atlanta, Georgia.

Blair, J. P., \& Carroll, M. C. (2008). Local Economic Development: Analysis, Practices, and Globalization. Los Angeles: Sage.

Calderón, C., \& Liu, L. (2002).The Direction of Causality between Financial Development and Economic Growth.Central Bank of Chile (Working Papers No. 184). Retrieved 10-30-2012 From http://www.comisiondistorsionesdeprecios.cl/eng/studies/workingpapers/pdf/dtbc184.pdf

Cerra, V., \&Saxena, S. (2008). Growth Dynamics: The Myth of Economic Recovery. American Economic Review, 98 (1), 439-457.

Chong, A., \& Calderon, C. (2000). Casualty and Feedback Between Institutional Measurement and Economic Growth. Economic and Politics, 12 (1), p. 69-81.

Claessens, S., \&Kose, M. A. (2009). What Is a Recession? Finance and Development, 46 (1), 52-53.

Constanza, R., M. Hart, S. Posner, \& J. Thalbert (2009).Beyond GDP: The Need for New Measures of Progres. The Pardee Papers (Technical Report 4). Retrieved 10/18/2010 from http://www.bu.edu/pardee/files/documents/PP-004-GDP.pdf.

Davidoff, S. M., \&Zaring, D. (2008).Regulation by Deal: The Government's Response to the Financial Crisis. Retrieved 03-17-2012 from http:// ssrn.com/abstract=1306342.

de Ferranti, D. M., Jacinto, J., Ody, A., \&Ramshaw, G. (2009). How to Improve Governance: A New Framework for Analysis and Action. Washington, D.C: Brookings Institution Press.

De Long, J. \& Summers, L. (1991).Equipment Investment and Economic Growth. The Quarterly Journal of Economics, 106 (2), 445-502.

Dixit, A. (2009). Governance Institutions and Economic Activities. American Economic Review, 99 (1), 5-24.

Farazmand, A. (2004). Sound Governance: Policy and Administrative Innovations, (Ed.). New York, NY: Praeger.

Frahm, K. A., \& Martin, L. L. (2009). From Government to Governance: Implications for Social Work Administration. Administration in Social Work, 33, 407-422.

Furubotn, E. G. \& Richter, R. (2005).Institutions and Economic Theory: the Contribution of the New Institutional Economics (2nd ed.). Ann Arbor, Michigan: University of Michigan Press.

Gressani, D., \&Kouame, A. T. (2009).The Global Financial \&Economic Crisis: Transmission Channels $\&$ Policy Response in the Arab World. MENA Learning and Knowledge, (World Bank Quick Note No. 1).Retrieved09-21-2010 from http:// siteresources.worldbank.org/INTMENA/News\%20and\%20Events/22073725/ QuickNote_1.pdf.

Grindle, M. (2007). Good Enough Governance Revisited. Development Policy Review, 25 (5), p. 553574.

Gruenewald, S. (2010).Financial Crisis Containment and its Governance Implications.Journal of Banking Regulation, 12 (1), 69-90.

Harttgen, K., Klasen, S., \& Vollmer, S. (2012). Economic Growth and Child Undernutrition in Africa. United Nation Development Program (Working Paper No. 2012-013). Retrieved 10-30-2012 From http://web.undp.org/africa/knowledge/WP-2012-013-Harttgenklassen-economic-growth-undernutrition.pdf

Hysing, E. (2009). From Government to Governance?A Comparison of Environmental Governing in Swedish Forestry and Transport.Governance: An International Journal of Policy, Administration, and Institutions, 22 (4), 647-672.

Ignatiuk, A. (2009). The Principle, Practise and Problems of Purchasing Power Parity Theory. Santa Cruz, CA: GRIN Verlag. 
International Monetary Fund (IMF). (2010, October 13). World Economic Outlook (WEO): Recovery, Risk, and Rebalancing. Retrieved 03-11-2012 from http://www.imf.org/external/pubs/ft/weo/2010/02/index.htm.

Islam, M. (1998). Export Expansion and Economic Growth: Testing for Cointegration and Causality. Applied Economics, 30 (3), 415-425.

Kaufmann, D., \&Kraay, A. (2002).Growth without Governance [with Comments].Economia, 3 (1), 169229.

Kaufmann, D., Kraay, A., \&Mastruzzi, M. (2010).The Worldwide Governance Indicators: Methodology and Analytical Issues (World Bank Policy Research Working Paper No. 5430). Washington, DC: The World Bank.

Kaufmann, D., Kraay, A. and Mastruzzi, M. (2009).Governance matters 2009: Learning From Over a Decade of the Worldwide Governance Indicators. Retrieved 2/10/10 from http://info.worldbank.org/governance/wgi/index.asp.

Kentor, J. (1998). The Long-Term Effects of Foreign Investment Dependence on Economic Growth 1940-1990. American Journal of Sociology. 103 (4), 1024-1046.

Kettl, D. (2002). The Transformation of Governance: Public Administration for Twenty-First Century America (Interpreting American Politics). Baltimore, Maryland: The Johns Hopkins University Press.

Langmore, J., \&Fitzgerlad, S. (2010). Global Economic Governance: Addressing the Democratic Deficit. Development, 53(3), 390-393.

Lovan, R., \& Shaffer, R., \& Murray, M. (2004).Participatory Governance: Planning, Conflict Mediation and Public-Decision Making in Civil Society. London, U.K: Ashgate Publishing.

Mankiw, N. G. (2009). Principles of Economics (5th ed.). Mason, OH: South-Western Cengage Learning.

Mantzavinos, C. (2001). Individuals, Institutions, and Markets. Cambridge, UK: Cambridge University.

Mayer-Foulkes, D. A. (2009).Long-Term Fundamentals of the 2008 Economic Crisis.Global Economy Journal, 9 (4), 1-24.

Mehanna, R., Yazbeck, Y., \&Sarieddine, L. (2010). Governance and Economic Development in MENA Countries: Does Oil Affect the Presence of a Virtuous Circle?.Journal of Transnational Management, 15 (2), p. 117-150.

Mimicopoulos, M., Kyj, L., \&Sormani, N. (2007).Public Governance Indicators: a Literature Review. New York, NY: United Nations publications.

Nafziger, E. W. (2006). Economic Development (4th ed.). Cambridge: Cambridge University.

National Bureau of Economic Research (NBER) (2012).Determination of the December 2007 Peak in Economic Activity. Retrieved 2012-03-04 from http:/ /www.nber.org/dec2008.pdf

National Bureau of Economic Research (NBER). (2003, October 21). Business Cycle Dating Committee. Retrieved 03-08-2012 from http://www.imf.org/external/pubs/ft/fandd/2009/03/pdf/fd0309.pdf

Ndulu, B. J., \& O'Connell, S. A. (1999).Governance and Growth in Sub-Saharan Africa.The Journal of Economic Perspectives, 13 (3), pp. 41-66.

Newman, J. (2001). Modernizing Governance: New Labour, Policy and Society. Thousand Oaks, CA: Sage Publications Ltd.

Nguyen, N. M. (2005). Note: Purchasing Power Parity. Washington, D.C: IMF. Retrieved 6/21/2011 from http://people.hbs.edu/mdesai/IFM05/PPP\%20Nguyen.pdf.

North, D.C. (1990). Institutions, Institutional Change and Economic Performance (Political Economy of Institutions and Decisions). Cambridge, UK: Cambridge University Press

Osborne, D. ,\&Gaebler, T. (1992). Reinventing Government: How the Entrepreneurial Spirit Is Transforming the Public Sector. New York, NY: Basic Books. 
Peters, B.G., \& Pierre, J. (1998).Governance without Government?Rethinking Public Administration.Journal of Public Administration Research and Theory, 8 (2), 223-243.

Petrovskiy, V. (2009). New Paradigm of Global Governance: Challenges and Opportunities for EU-Russia Relations. In Nijitin, A. (Eds.), Lessons to be Learned from Non-Proliferation Failures and Successes (pp. 126-138). Lansdale, PA: IOS Press.

Poluha, E., \&Rosendahl, M. (2002).Contesting 'Good' Governance: Crosscultural Perspectives on Representation, Accountability and Public Space. London, U.K: Rutledge.

Pradhan, R. P., \&Sanyal, G. S. (2011). Good Governance and Human Development: Evidence form Indian States. Journal of Social and Development Science, 1 (1), pp. 1-8.

Provan, K. G., \&Kenis, P. (2008). Modes of Network Governance: Structure, Management, and Effectiveness. Journal of Public Administration Research and Theory, 18 (2), 229-252.

Przeworski, A., Alvarez, M.E., Cheibub, J.A. \&Limongi, F. (2000).Democracy and Development: Political Institutions and Well-Being in the World, 1950-1990. Cambridge, United Kingdom: Cambridge University Press.

Reinhart, C. M., \&Rogoff, K. S. (2009).This Time is Different: Eight Centuries of Financial Folly. Princeton, New Jersey: Princeton University Press.

Repucci, S. (2011, March).Economic Crisis Responses from a Governance Perspective in Eastern Europe and Central Asia: Regional Report. United Nations Development Program (UNDP) (Regional Center for Public Administration Reform (RCPAR)). Retrieved 06-20-2012 from http://www.rcpar.org/mediaupload/publications/2011/20110325_Impact_of_Econom ic_Crisis_on_Governance_FINAL.pdf.

Rhodes, R. A. W. (1997). Understanding governance: Policy Networks, Governance, Reflexivity and Accountability (Public Policy \& Management). Berkshire, UK: Open University Press.

Sagar A. D., \&Najam, A. (1998). The Human Development Index: a Critical Review. Ecological Economics, 25, pp. 249-264.

Santiso, C. (2001). Good Governance and Aid Effectiveness: The World Bank and Conditionality. The Georgetown Public Policy Review, 7 (1), 1-22.

Shostak, F. (August 23, 2001). What is up with the GDP?. Auburn, Alabama: Ludwing Von Mises Institute. Retrieved 10/18/2012 from http://mises.org/daily/770.

Simkovic, M. (2011).Competition and Crisis in Mortgage Securitization.Harvard Law School (Working Paper \# 1924831) Retrieved 03-06-2012 from http://papers.ssrn.com/sol3/papers.cfm?abstract_id=1924831.

Sirimanne, S. (2009). Emerging issue: The gender perspectives of the financial crisis. Commission on the Status of Women Fifty-third session, New York, 2 - 13 March, United Nations.Retrieved 03-24-2010 from

http://www.un.org/womenwatch/daw/csw/csw53/panels/financial_crisis/Sirimanne.f ormatted.pdf.

Smith, B. (2007). Good Governance and Development. New York, NY: Palgrave Macmillan.

Statistics Denmark.(2009). Statistical Yearbook 2009 (SY09).Retrieved 03-07-2012 from http://www.dst.dk/pukora/epub/upload/14468/sy2009.pdf.

Statistics Estonia.(2012). Statistical Database.Retrieved 03-07-2012 from http://pub.stat.ee/pxweb.2001/Dialog/statfile1.asp.

Thomas, M. (2008). What do the worldwide governance indicators measure? Retrieved 4/20/10 from http://www.sais-jhu.edu/bin/q/r/What $\% 20$ Do $\% 20$ the $\% 20$ Worldwide $\% 20$ Governance\%20 Indicators\%20Measure.pdf.

United Nations (UN). (2007). Good Governance Practices for the Protection of Human Rights. New York, NY: United Nations Press.

United Nations (UN). (2000). “We Can End Poverty 2015: Millennium Development Goals" New York. Retrieved 06/14/2011 from www.un.org/millenniumgoals/. 
United Nations Conference on Trade and Development (UNCTD) (2009).World Investment Report 2009. New York, NY: United Nations Publications. Retrieved 03-23-2010 from http://unctad.org/en/docs/wir2009_en.pdf

United Nations Development Program (UNDP) (2010). Human Development Report 2010 20th Anniversary Edition. The Real Wealth of Nations: Pathways to Human Development. (2nd ed.). New York, NY: Palgrave Macmillan. Retrieved 06-26-2011 from http://hdr.undp.org/en/media/HDR_2010_EN_Complete_reprint.pdf.

United Nations Economic and Social Commission for Asia and the Pacific (UNESCAP). (2009). What is Governance? Retrieved 02/10/2011 from http://www.unescap.org/pdd/prs/ProjectActivities/Ongoing/gg/governance.pdf.

Vachris, M. A., \& Thomas, J. (1999). International Price Comparisons based on Purchasing Power Parity. Monthly Labor Review, 122 (10), 3-12.

van den Bergh, J. (2009). The GDP paradox.Journal of Economic Psychology, 30 (2), 117-135.

Wong, P., Ho, P., \&Autio, E. (2005). Entrepreneurship, Innovation and Economic Growth: Evidence from GEM data. Small Business Economics, 24, 335-350.

World Bank.(2004). Beyond Economic Growth Student Book.Retrieved 04/04/2012 from http://www.worldbank.org/depweb/english/beyond/global/glossary.html.

World Bank.(2012a). Data.Retrieved 03-11-2012 from http://data.worldbank.org/indicator/NY.GDP.PCAP.PP.CD.

Yap, J. T., Reyes, C. M., \& Cuenca, J. S. (2009).Impact of the Global Financial and Economic Crisis on the Philippines. Philippine Institute for Development Studies (Discussion Paper Series NO. 2009-30). Retrieved 02-24-2011 from http://www.unicef.org/socialpolicy/files/Impact_of_the_Global_Finanical_and_Econ omic_Crisis_on_the_Philippines.pdf. 